\title{
Rola sirtuin w naprawie DNA
}

\section{mgr Mateusz Kciuk ${ }^{1,2 \boxminus, ~}$}

\section{dr hab. Renata Kontek ${ }^{1}$}

${ }^{1}$ Katedra Biotechnologii Molekularnej i Genetyki, Wydział Biologii i Ochrony Środowiska, Uniwersytet Łódzki

${ }^{2}$ Szkoła Doktorska Nauk Ścisłych i Przyrodniczych UŁ Wydział Biologii i Ochrony Środowiska, Uniwersytet Łódzki

https://doi.org/10.18388/pb.2020_319

凶autor korespondujący: mateusz.kciuk@unilodz.eu

Słowa kluczowe: naprawa DNA, sirtuiny

Wykaz skrótów: APE (ang. apurinic/apyrimidinic (AP) endonuclease) - endonukleaza apurynowa/apirymidynowa; BER (ang. base excision repair) - naprawa przez wycinanie zasad; BRCA1 (ang. breast cancer type 1 susceptibility protein); DDR (ang. DNA damage response) - szlak odpowiedzi na uszkodzenia DNA; FOXO (ang. forkhead box transcription factors) - czynniki transkrypcyjne $\mathrm{z}$ rodziny forkhead; GADD45 (ang. growth arrest and DNA-damage-inducible a) - białko indukowane uszkodzeniami DNA, hamujące wzrost komórki; HIC1 (ang. hypermethylated in cancer 1 ) - białko hipermetylowane w komórkach nowotworowych; HR (ang. homologous recombination) - rekombinacja homologiczna; NER (ang. nucleotide excision repair) - naprawa przez wycinanie nukleotydów NHEJ (ang. non-homologous end joining) - niehomologiczne łączenie końców; PARP $_{\mathrm{S}}$ (ang. poly (ADP-ribose) polymerase) - polimerazy poli(ADP-rybozy); RSR (ang. replicative stress response) - odpowiedź na stres replikacyjny; SIRT (ang. sirtuin) - sirtuina

\section{STRESZCZENIE}

Taprawa DNA związana jest z szeregiem procesów prowadzących do identyfikacji i na1 prawy zmian powstałych w cząsteczkach DNA. Zdolność komórki do naprawy DNA jest istotna nie tylko dla integralności fizycznej całego genomu, ale również dla integralności informacji genetycznej, a więc i dla prawidłowego funkcjonowania całego organizmu. Naprawa DNA zapobiega szkodliwym wpływom czynników uszkadzających, zarówno będących produktem prawidłowego metabolizmu, jak i pochodzących ze środowiska zewnętrznego komórki. Istotną rolę w prawidłowym funkcjonowaniu systemów naprawczych odgrywają białka o nazwie sirtuiny. Należą one do deacetylaz histonów, które usuwają grupy acetylowe z reszt lizynowych wielu białek, jak również biorą udział w ich potranslacyjnej modyfikacji działając jako transferazy mono-ADP rybozylowe. Wykryte zostały w drożdżach (Saccharomyces cerevisiae), ale ich obecność została potwierdzona zarówno u prokariontów, jak i eukariontów. W komórkach ssaków oznaczane są symbolami SIRT1-SIRT7. Konserwatywne ewolucyjnie sirtuiny stanowią istotne ogniwo łączące metabolizm komórki z naprawą DNA. W niniejszej pracy zebrane zostały informacje dotyczące regulacji aktywności sirtuin, interakcji między nimi a innymi elementami komórki oraz roli, jakie pełnią w procesie naprawy DNA komórek eukariotycznych. Aktywność sirtuin ma związek z rokowaniem w schorzeniach związanych ze starzeniem organizmu, takich jak choroby neurodegeneracyjne, cukrzyca czy nowotwory.

\section{SIRTUINY - OGÓLNA CHARAKTERYSTYKA}

Sirtuiny (SIRT; ang. Silent Information Regulator) stanowią grupę zachowanych ewolucyjnie białek, których obecność wykazano we wszystkich domenach życia. Swoją nazwę wywodzą od genu Sir2 (ang. Silent information regulator 2), zidentyfikowanego po raz pierwszy w komórkach drożdży Saccharomyces cerevisiae. Jego produkt reguluje rekombinację rybosomalnego DNA oraz uczestniczy w wyciszaniu ekspresji innych genów i naprawie DNA [1]. Sirtuiny zaangażowane są w wiele ważnych procesów biologicznych: regulację transkrypcji, naprawę DNA, utrzymywanie stabilności chromosomów, metabolizm lipidów oraz cukrów czy regulację poziomu stresu oksydacyjnego. Dlatego, zaburzenia działania sirtuin odgrywają rolę w patogenezie niektórych chorób związanych z wiekiem.

Budowa sirtuin oraz ich rola w regulacji metabolizmu została dokładnie opisana w 2019 roku przez Frydzińską i wsp., stąd w szczegółach nie będzie przedmiotem niniejszego opracowania [2]. Sirtuiny to białka należące do deacetylaz, które w reakcji zależnej od $\mathrm{NAD}^{+}$usuwają grupy acetylowe z reszt lizynowych wielu białek. Ponadto, mogą funkcjonować jako transferazy mono-ADP rybozylowe, które przeprowadzają potranslacyjną modyfikację białek tj. mono-ADP rybozylację. Najbliższym ewolucyjnie homologiem drożdżowego białka Sir2 w komórkach ludzkich jest SIRT1. Obecnie u ludzi znanych jest siedem jego homologów, które różnią się między sobą lokalizacją w komórce: SIRT1 i SIRT2 znajdują się zarówno w jądrze komórkowym, jak i w cytoplazmie, SIRT3, SIRT4 oraz SIRT5 są białkami charakterystycznymi dla mitochondriów, natomiast SIRT6 oraz SIRT7 należą do białek jądrowych [2,3]. Długość wszystkich ww. białek waha się od 310 do 747 aminokwasów. Sirtuiny 1 i 6 zlokalizowane w obrębie jądra komórkowego wpływają na znajdujące się tam czynniki transkrypcyjne. Deacetylacja przez sirtuinę 1 czynnika transkrypcyjnego FOXO1 (ang. Forkhead Box Protein O1) powoduje jego aktywację, co prowadzi do zwiększenia transkrypcji genów glukoneogenezy oraz aktywacji ekspresji czynników transkrypcyjnych regulujących działanie genów insuliny. Z kolei, sirtuina 6 powodując deacetylację i fosforylację acetylotransferazy GCN5 działa hamująco na czynnik transkrypcyjny PGC-1a (ang. Peroxisome Proliferator-activated Receptor Gamma Coactivator 1a), spowalniając przebieg glukoneogenezy. Obie ww. sirtuiny w wyniku deacetylacji powodują unieczynnienie czynnika transkrypcyjnego HIF1 (czynnik transkrypcyjny indukowany hipoksją) przez co następuje osłabienie tempa transkrypcji genów procesu glikolizy. SIRT1 i SIRT6 deacetylują również 
czynnik transkrypcyjny SREBP-1 (ang. Sterol Regulatory Element Binding Protein 1), obniżając ekspresję genów, których produkty regulują proces lipogenezy i syntezy cholesterolu. Ponadto, sirtuina 1 poprzez oddziaływanie z kofaktorami czynnika transkrypcyjnego PPARY (ang. Peroxisome Proliferator-activated Receptor- $\gamma$ ) prowadzi do jego inhibicji, regulując w ten sposób metabolizm lipidów. Sirtuina 6 hamuje aktywność czynnika transkrypcyjnego MYC odpowiedzialnego za transkrypcję genów białek oraz rybosomalnego RNA. Zdarza się, że to czynniki transkrypcyjne takie jak: RUNX2 czy E2F1 stają się represorami aktywności SIRT6. Poza tym, substraty sirtuin mogą pełnić rolę czynników transkrypcyjnych i tym samym, wpływać na aktywność enzymatyczną białek oraz enzymów glikolitycznych występujących na terenie cytoplazmy. Sirtuiny mitochondrialne (SIRT3-5) wpływają na przebieg cyklu Krebsa i funkcjonowanie łańcucha oddechowego. Odmienna lokalizacja komórkowa sirtuin wynika najprawdopodobniej z różnic składu aminokwasowego końca $\mathrm{N}$ oraz C enzymu [2].

\section{NAPRAWA DNA}

Komórki ludzkiego ciała są stale narażone na działanie licznych czynników uszkadzających DNA, które mogą pochodzić zarówno ze środowiska zewnętrznego (promieniowanie UV, promieniowanie jonizujące), ale i wewnętrznego (błędy replikacyjne, uszkodzenia oksydacyjne, hydrolityczne, pęknięcia nici) [4]. W odpowiedzi na tak zróżnicowany charakter czynników uszkadzających DNA, w komórkach eukariotycznych został rozwinięty system, który zapewnia integralność genomu, nazwany szlakiem odpowiedzi na uszkodzenia DNA (DDR, ang. DNA damage response). Rodzaj uszkodzenia DNA determinuje sposób jego naprawy, jednakże wszystkie systemy naprawcze łączy podobny schemat działania. Większość odpowiedzi na uszkodzenia opiera się na złożonej sekwencji zdarzeń, w
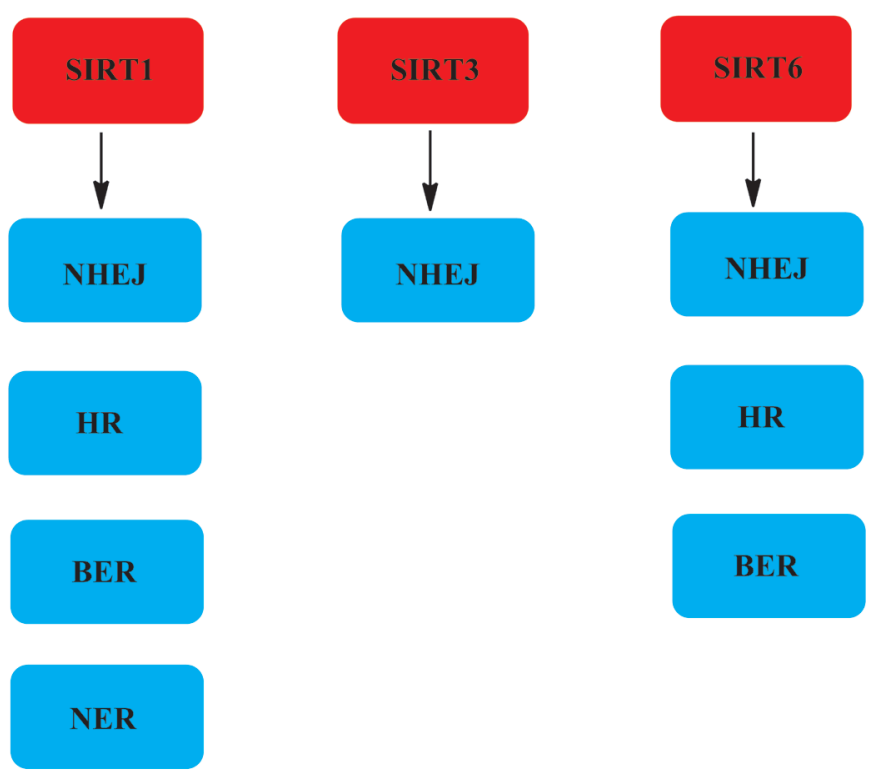

Rycina 1. Udział sirtuin w głównych systemach naprawy DNA. Wykaz skrótów: BER (ang. base excision repair) - naprawa przez wycinanie zasad; HR (ang. homologous recombination) - rekombinacja homologiczna; NER (ang. nucleotide excision repair) - naprawa przez wycinanie nukleotydów; NHEJ (ang. non-homologous end joining) - naprawa przez niehomologiczne łączenie końców; SIRT (ang. sirtuin) - sirtuina. której uczestniczy wiele wyspecjalizowanych białek. Tworzą one swoistą kaskadę sygnalizacyjną prowadzącą do naprawy uszkodzenia, ,przetwarzania” RNA, remodelowania chromatyny, transkrypcji, apoptozy, autofagii czy starzenia komórkowego. Aktywacja szlaku DDR prowadzi do uruchomienia punktów kontrolnych cyklu komórkowego i zatrzymania podziałów, co uniemożliwia przekazanie uszkodzonego DNA do komórek potomnych. Jednocześnie zostają aktywowane mechanizmy naprawy DNA zapewniające stabilność informacji genetycznej komórki. Głównymi systemami naprawy DNA są: rekombinacja homologiczna (ang. homologous recombination; HR), niehomologiczne łączenie końców (ang. non-homologous end joining; NHEJ), naprawa przez wycinanie zasad azotowych (ang. base excision repair; BER), naprawa przez wycinanie nukleotydów (ang. nucleotide excision repair; NER) oraz naprawa pęknięć jednoniciowych (ang. single strand break repair; SSBR), która przez wielu uznawana jest za podtyp BER (Tabela 1) [5]. Kluczową rolę w regulacji głównych systemów naprawczych odgrywają sirtuiny (SIRT1-7) (Ryc. 1).

\section{SIRTUINA 1}

Sirtuina 1 (SIRT1) może modulować naprawę DNA poprzez deacetylację chromatyny, co w większości przypadków, prowadzi do jej kondensacji, przez co reguluje dostęp białek naprawczych do miejsca uszkodzenia (Ryc. 3). Celem działania białka SIRT1 są głównie acetylowane reszty lizyny w pozycjach 26 histonu H1, 9 i 56 histonu H3 oraz 16 histonu H4 [6].

Sirtuina 1 przez długi czas uważana była za białko będące promotorem transformacji nowotworowej. Zwiększoną aktywność tego białka obserwowano w wielu typach nowotworów [7]. Inne badania sugerują, że obniżona aktywność sirtuiny 1 może przyczyniać się do genetycznej niestabilności, przez co można przypuszczać, że funkcjonuje jako białko supresorowe [8].

Bezpośrednia interakcja fizyczna SIRT1 z białkiem TP53 reguluje jego aktywność. Ponadto, poprzez deacetylacje wielu lizyn, w tym Lys ${ }^{320}$, Lys $^{373}$ oraz Lys ${ }^{382}$ sirtuina 1 hamuje aktywność transaktywacyjną białka TP53, zapobiegając apoptotycznej śmierci komórki w odpowiedzi na uszkodzenia DNA. W ten sposób przyczynia się do zaindukowania transformacji nowotworowej $[9,10]$.

W regulacji osi SIRT1-TP53 kluczową rolę odgrywa białko HIC1 (ang. Hypermethylated in Cancer 1). HIC1 tworzy z SIRT1 kompleks represyjny wiążący się z promotorem genu SIRT1, hamując w ten sposób jego transkrypcję. Inaktywacja HIC1 nasila aktywność białka SIRT1, które poprzez deacetylację inaktywuje białko TP53, zapobiegając apoptozie komórki, pomimo akumulacji uszkodzeń DNA. W komórkach, w których naprawa DNA przebiega sprawnie, spadek stężenia białka TP53 może prowadzić do obniżenia aktywności HIC1, a w konsekwencji zwiększonej syntezy białka SIRT1 utrzymującej TP53 w stanie nieaktywnym (Ryc. 2) [11].

Innym kluczowym białkiem zaangażowanym w przebieg cyklu komórkowego jest czynnik transkrypcyjny E2F1, 


\begin{tabular}{ll}
\hline $\begin{array}{l}\text { Nystem naprawy DNA przez wycinanie zasad azotowych } \\
\text { (BER), naprawa pęknięć jednoniciowych (SSB) }\end{array}$ & $\begin{array}{l}\text { Rodzaj uszkodzedzenia pojedynczych zasad przez oksydację, alkilację, hydrolizę czy deaminację, } \\
\text { addukty zasad azotowych, błędna/nieskuteczna aktywnośc topoizomerazy }\end{array}$ \\
Naprawa przez wycinanie nukleotydów (NER) & obszerne addukty zasad azotowych, fotoprodukty UV \\
Niehomologiczne łączenie końców (NHEJ) & pęknięcia dwuniciowe \\
Rekombinacja homologiczna (HR) & $\begin{array}{l}\text { pęknięcia dwuniciowe, zatrzymane widełki replikacyjne, międzyniciowe } \\
\text { wiązania krzyżowe (ICL), błędna/nieskuteczna aktywność topoizomerazy }\end{array}$
\end{tabular}

który ma zdolność do wiązania się z promotorem genu SIRT1, aktywując jego ekspresję. Jednocześnie sirtuina jest inhibitorem E2F1, co prowadzi do utworzenia pętli EF21-SIRT1 (Ryc. 2). Oddziaływanie to chroni komórkę przed uszkodzeniami DNA, co udowodniono $\mathrm{w}$ badaniach in vitro z wykorzystaniem komórek raka płuc (H1299) oraz komórek wywodzących się z kostniakomięsaka (U20S) [12].

Białko SIRT1 może funkcjonować jako promotor transformacji nowotworowej poprzez epigenetyczną represję aktywacji genów supresorowych oraz białek zaangażowanych w naprawę DNA. SIRT1 reguluje przetrwanie komórki poprzez regulację aktywności czynników transkrypcyjnych rodziny FOXO (ang. forkhead family of transcription factors) $[13,14]$. W odpowiedzi na czynniki uszkadzające, SIRT1 poprzez oddziaływanie z FOXO3a, indukuje ekspresję genów zaangażowanych w naprawę DNA oraz regulację cyklu komórkowego $[15,16]$. SIRT1 odwraca również acetylację FOXO4 wywoływaną nadtlenkiem wodoru, indukując białko GADD45 (ang. growth arrest and DNA-damage-inducible a) w odpowiedzi na stres oksydacyjny $[17,18]$. Białko to odgrywa kluczową rolę w odpowiedzi na uszkodzenia DNA, bierze udział w zatrzymaniu cyklu komórkowego oraz naprawie DNA [19]. Firestein i wsp. wykazali, że białko SIRT1 może funkcjonować jako supresor transformacji nowotworowej komórek mysich $A P C^{\mathrm{min} /+}$. Wzrost aktywacji białka SIRT1 ogranicza rozwój nowotworu jelita grubego poprzez deacetylację $\beta$-kateniny oraz delokalizację onkogennej formy $\beta$-kateniny z jądra do cytoplazmy [20].

Obniżoną aktywność białka SIRT1 obserwuje się w przypadku nowotworów piersi związanych z mutacjami genu BRCA1 (ang. breast cancer type 1 susceptibility protein), kluczowego w naprawie pęknięć dwuniciowych. Jednocześnie BRCA1 wykazuje zdolność do wiązania się z promotorem genu SIRT1 i indukuje ekspresję docelowego genu. Spadek aktywności białka SIRT1 w komórkach, w których występują mutacje genu BRCA1, przyczynia się do ich transformacji nowotworowej. Wskazuje to na istotną rolę supresorową sirtuiny 1. SIRT1 wykazuje również aktywność proapoptotyczną poprzez negatywną regulację aktywacji białka surwiwiny. Inaktywacja związana jest z deacetylacją lizyn w pozycji 9 histonów H3 w regionie promotorowym antyapoptotycznego genu surwiwiny [21].

SIRT1 może bezpośrednio deacetylować, i tym samym aktywować, wiele białek naprawy pęknięć dwuniciowych DNA, w tym białka Ku, NBS1 oraz helikazę Wernera (Ryc. 3) [22-24]. Komórki pozbawione sirtuiny 1 charakteryzują się zmniejszoną zdolnością naprawy uszkodzeń powodowanych przez promieniowanie $\gamma$ oraz zmniejszoną liczbą skupisk białek naprawczych - үH2AX, BRCA1, NBS1 oraz RAD51 w miejscach uszkodzenia [8]. Ponadto, efektywna rekrutacja SIRT1 do DSB wymaga sygnalizacji z udziałem kinazy ATM oraz histonu H2AX [8,25]. Innymi białkami aktywującymi SIRT1 są kinazy punktów kontrolnych cyklu komórkowego. Wykazano, że CHK1 aktywuje SIRT1 poprzez fosforylację enzymu na resztach treoniny - Thr ${ }^{530}$ oraz $\mathrm{Thr}^{540}$ [26]. Możliwymi konsekwencjami obniżonych zdolności naprawczych pęknięć dwuniciowych DNA są liczne translokacje oraz fuzje chromosomalne $[8,25]$.

Białko SIRT1 bierze także udział w kontroli aktywności endonukleazy AP (ang. apurinic/apyrimidinic ( $A P$ ) endonuclease). Kluczową modyfikacją potranslacyjną regulującą aktywność białka APE1 jest acetylacja lizyn na N-końcu

A
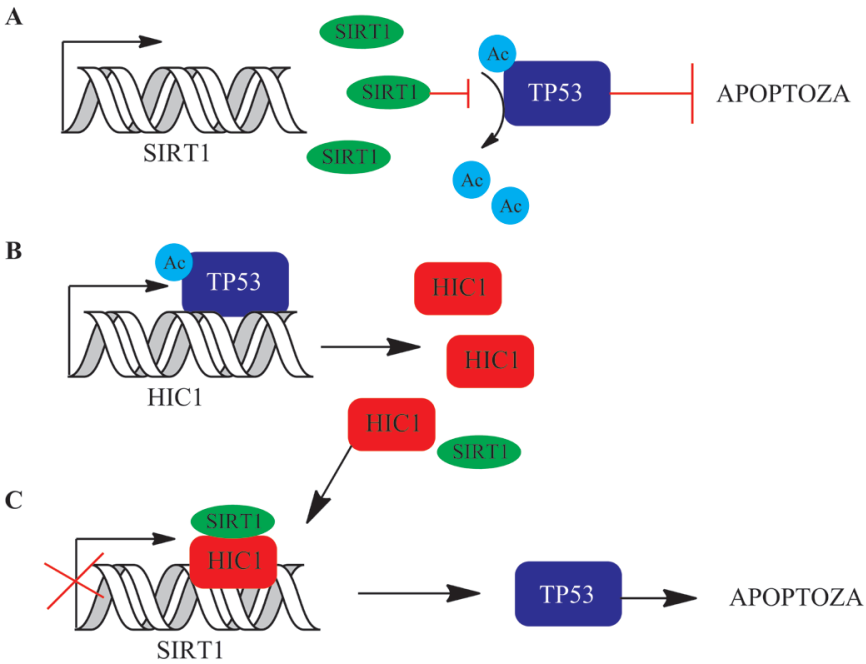

D

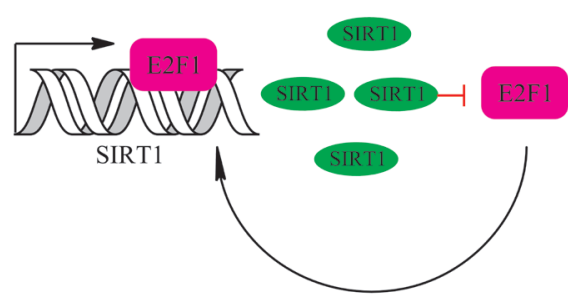

Rycina 2. Zależność między ekspresją/aktywnością SIRT1, a innymi białkami w procesie transkrypcji. (A) SIRT1 w reakcji deacetylacji reguluje aktywność białka TP53, prowadząc do obniżenia jego zdolności do indukcji apoptozy; (B) Acetylowane białko TP53 jest czynnikiem transkrypcyjnym wielu genów, w tym HIC1; (C) HIC1 z SIRT1 tworzy kompleks represyjny genów kodujących SIRT1, prowadząc do utworzenia osi SIT1-HIC1-TP53; (D) SIRT1 obniża aktywność E2F1 prowadzac do utworzenia petli EF21-SIRT1. Wykaz skrótów: E2F1 (ang. E2F Transcription Factor 1) - czynnik transkrypcyjny E2F1; TP53 (ang. Tumor Protein P53) - białko TP53; SIRT1 (ang. sirtuin 1) - sirtuina 1. 


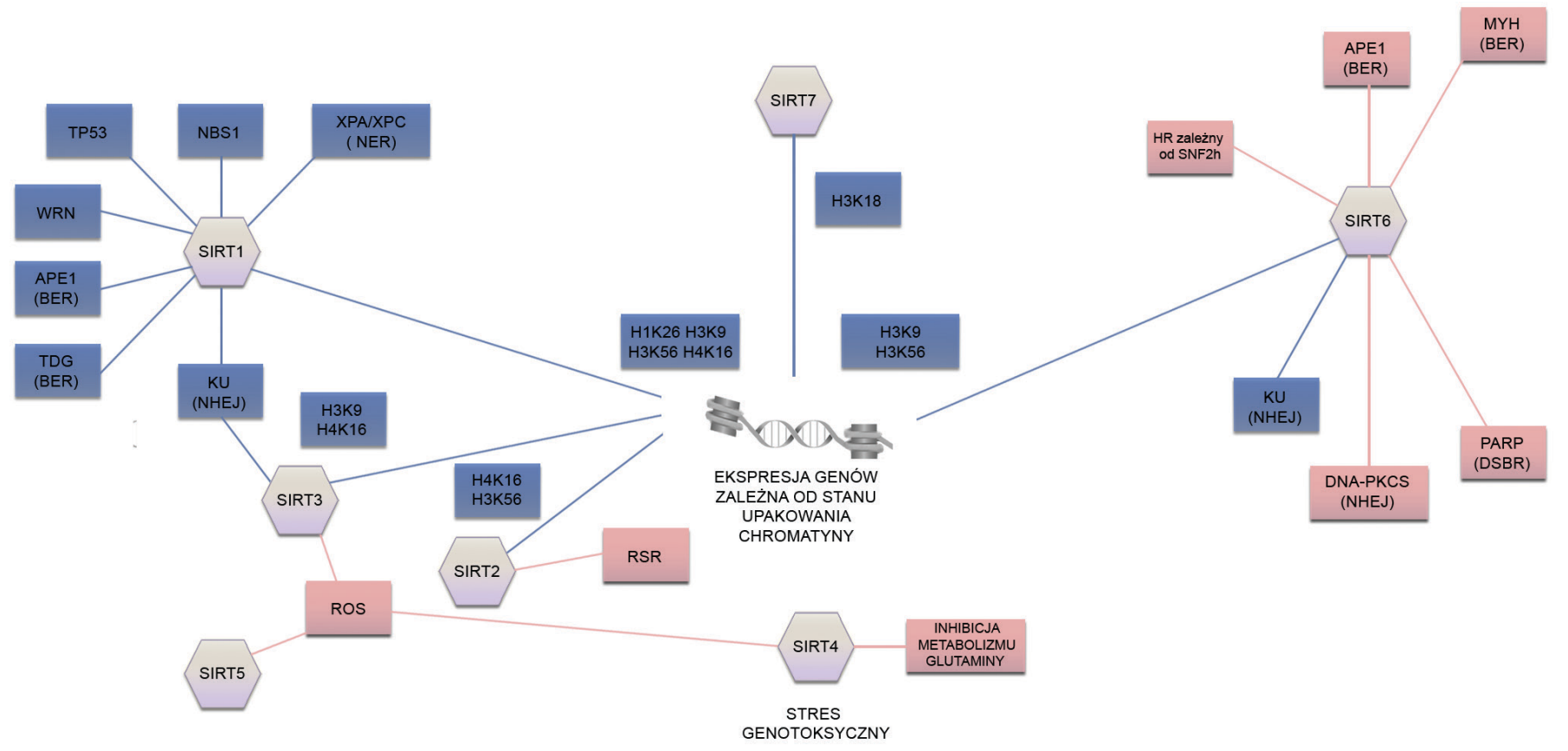

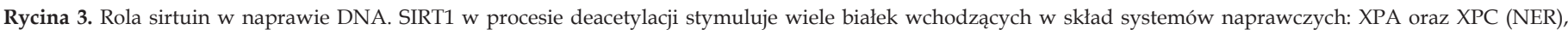

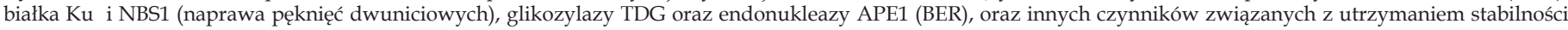

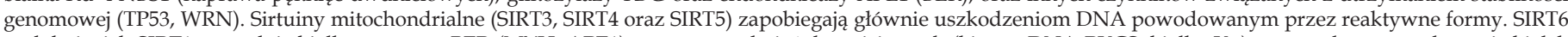

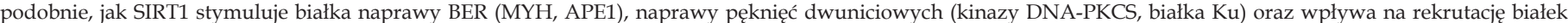

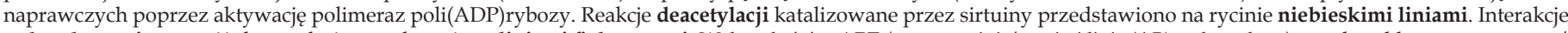

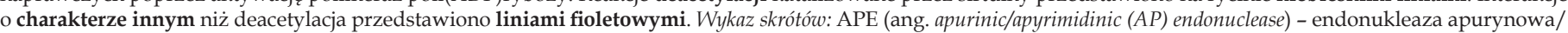

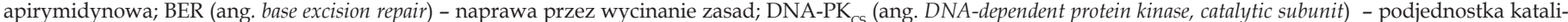

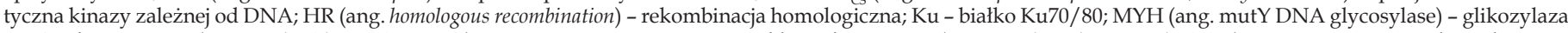

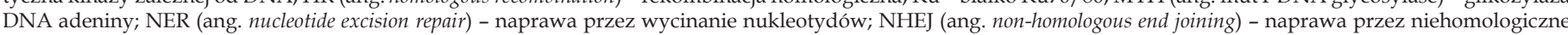

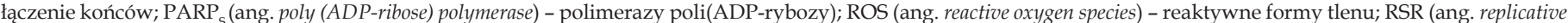

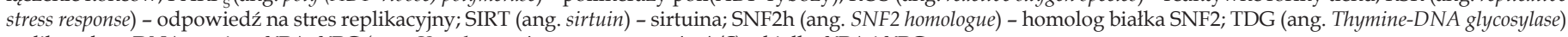
- glikozylaza DNA tyminy; XPA, XPC (ang. Xeroderma pigmentosum protein A/C) - białka XPA i XPC.

endonukleazy. SIRT1 deacetyluje APE1, co zwiększa aktywność enzymatyczną endonukleazy, chroniąc komórkę przed czynnikami genotoksycznymi oraz stresem oksydacyjnym [27]. SIRT1 może również deacetylować glikozylazę DNA tyminy - TDG (ang. thymine DNA glycosylase), stymulując jej aktywność (Ryc. 3) [28].

Sirtuina 1 wykazuje również działanie wspomagające naprawę DNA typu NER zaangażowaną w usuwanie uszkodzeń wywoływanych promieniowaniem UV. SIRT1 wchodzi w bezpośrednią interakcję $\mathrm{z}$ białkiem XPA, deacetulując Lys $^{63}$ oraz Lys ${ }^{67}$, zwiększając powinowactwo XPA do ERCC1-XPF i w ten sposób zapewniając efektywną naprawę DNA [29]. SIRT1 zwiększa również aktywność samego białka XPC (Ryc. 3) [30].

Jang i wsp., udowodnili, że SIRT1 moduluje poziom syntezy dwóch białek zaangażowanych w system naprawy błędnie sparowanych zasad - MSH2 i MSH3 oraz enzymu APEX1 zaangażowanego w naprawę BER. Inhibicja SIRT1 prowadzi do apoptotycznej śmierci komórek embrionalnych, ukazując tym samym kluczową rolę białka SIRT1 dla utrzymania stabilności genomowej ludzkich komórek embrionalnych [31].

SIRT1 moduluje również aktywność białek modyfikujących strukturę chromatyny - metylotransferaz histonowych i acetylotransferaz [32,33].

\section{SIRTUINA 2}

Białko SIRT2 odgrywa istotną rolę podczas odpowiedzi komórki na stres replikacyjny (RSR, ang. replicative stress response), przyczyniając się do utrzymania integralności genomowej (Ryc. 3). SIRT2 poprzez deacetylację kinazy zależnej od cyklin (CDK9) przyczynia się do jej aktywacji [34], a z kolei usunięcie grupy acetylowej lizyny w pozycji 16 histonu H4 (H4K16Ac) umożliwia metylację lizyny w pozycji 20 histonu H4 (H4K20) poprzez metylazę PR-Set7. Innymi substratami białka SIRT2 są acetylowane lizyny w pozycji 56 histonu H3, których deacetylacja umożliwia wejście komórki w mitozę $[35,36]$.

\section{SIRTUINY: 3-5}

Uszkodzenia jądrowego DNA prowadzą do aktywacji wielu szlaków sygnalizacyjnych. Jednym z najmniej poznanych szlaków jest szlak sygnalizacyjny obejmujący interakcję pomiędzy jądrem komórkowym i mitochondriami. W sygnalizacji tej bierze udział wiele białek zaangażowanych w naprawę jądrowego DNA, w tym kinazy ATM, PARP-1, TP53 oraz sirtuiny. Pomimo słabszego poznania mechanizmów naprawy mitochondrialnego DNA, charakteryzują się one sprawnym funkcjonowaniem systemu BER, bezpośredniej rewersji uszkodzeń, MMR oraz DSBR. Nie wykazano natomiast aktywności systemu NER w tym organellum [37]. 
Z uwagi na mitochondrialną lokalizację SIRT3, SIRT4 oraz SIRT5, nie biorą one udziału $\mathrm{w}$ naprawie jądrowego DNA. Ich funkcja związana jest z ochroną komórki przed uszkodzeniami oksydacyjnymi generowanymi $\mathrm{w}$ procesie oddychania komórkowego w mitochondriach. SIRT3 reguluje m.in. wytwarzanie reaktywnych form tlenu poprzez regulację równowagi redoks utrzymywanej przez glutation. Białko SIRT3, podobnie jak SIRT1, deacetyluje białka Ku70, a ponadto wykazuje aktywność deacetylazy histonów w stosunku do H3K9 oraz H4K16 w warunkach in vitro. Z kolei, białko SIRT4 chroni genom komórki zapobiegając wejściu glutaminy w cykl kwasów trójkarboksylowych, obniżając aktywność dehydrogenazy glutaminianowej i zatrzymując cykl komórkowy. Zapewnia w ten sposób komórce wystarczającą ilość czasu na naprawę uszkodzenia DNA. (Ryc. 3) $[3,6,38]$.

\section{SIRTUINA 6}

Sirtuina 6 (SIRT6) jest białkiem zaangażowanym w utrzymywanie prawidłowej struktury telomerów. Zapobiega fuzjom chromosomalnym, zapewniając efektywną naprawę DNA w rejonach telomerowych. Podobnie jak sirtuina 1, białko SIRT6 reguluje ekspresję genów poprzez kontrolowanie acetylacji białek histonowych. Zidentyfikowanymi substratami dla białka SIRT6 są białka histonowe zawierające acetylowane lizyny w pozycjach 9 i 56 histonu H3 (H3K9, H3K56). Umożliwia w ten sposób sprawną asocjację helikazy WRN z chromatyną, zapewnia sprawność procesu replikacji oraz reguluje metabolizm telomerów. Spadek aktywności białka SIRT6 prowadzi do niestabilności genomowej oraz nadwrażliwości na metylometanosulfonian, nadtlenek wodoru oraz promieniowanie jonizujące. Skutkiem defektów SIRT6 jest obniżona zdolność komórki do naprawy dwuniciowych pęknięć DNA [39,40].

Białko SIRT6 bierze udział w niehomologicznym łączeniu końców poprzez interakcję z podjednostką katalityczną kinazy zależnej od DNA (ang. DNA-dependent protein kinase, catalytic subunit) (DNA-PKcs) i białkiem Ku70/80. Wspomaga ich asocjację $\mathrm{z}$ chromatyną poprzez deacetylacje histonu H3K9 oraz deacetylację lizyn - Lys ${ }^{539}$ oraz Lys ${ }^{543}$ białka Ku70 (Ryc. 3). Ponadto, sirtuina 6 pomaga stabilizować białko DNA-PKcs w miejscach uszkodzenia, wspomagając naprawę pęknięcia i przyczyniając się do utrzymania stabilności genomowej [39,41].

Białko SIRT6 wchodzi również $\mathrm{w}$ interakcję z polimerazą poli(ADP-rybozy) - PARP1 (ang. poly(ADP-ribose) polymerase) przeprowadzając mono-ADP rybozylację Lys ${ }^{521}$ enzymu, zwiększając jego aktywność i przyczyniając się do bardziej efektywnej sygnalizacji uszkodzenia (Ryc. 3) [42]. Aktywność białka PARP1 prowadzi do relaksacji struktury chromatyny poprzez modyfikację białek histonowych $\mathrm{H} 1$ oraz H2B, co umożliwia białkom naprawczym, takim jak XRCC1 i polimerazie $\beta$ dostęp do uszkodzenia podczas naprawy BER [43]. Białko SIRT6 ma również wpływ na prawidłowe funkcjonowanie systemu BER poprzez stymulację aktywności glikozylazy MYH (ang. mutY DNA glycosylase) i endonukleazy APE1 (Ryc. 3). SIRT6 wchodzi również w interakcję z kompleksem Rad9-Rad1-Hus1 przyczyniając się do efek- tywnej rekrutacji helikazy WRN w miejsce zatrzymanych widełek replikacyjnych [44]. SIRT6 jest również jednym z białek, które najwcześniej rekrutowane jest do naprawy pęknięć nici DNA. Ponadto, sirtuina 6 rekrutuje białko remodelujące chromatynę SNF2h przyczyniając się do utworzenia jej otwartej struktury, umożlwiającej dostęp białek naprawczych - 53BP1(ang. p53-binding protein 1), RPA (ang. replication protein $A$ ) oraz BRCA1 do miejsc uszkodzenia (Ryc. 3) [45]. Białko SIRT6 odgrywa kluczową rolę w utrzymaniu stabilności genomowej komórek, szczególnie w odpowiedzi na stres oksydacyjny [42].

\section{SIRTUINA 7}

Białko SIRT7 jest najmniej poznaną sirtuiną będącą istotnym komponentem maszynerii transkrypcyjnej polimerazy RNA I [46]. Główną aktywnością enzymatyczną SIRT7 jest deacetylacja, jednak enzym ten posiada znacznie ograniczone spektrum substratu, w skład którego wchodzą acetylowane lizyny w pozycji 18 histonu 3 oraz białko TP53 (Ryc. 3) $[47,48]$. W komórkach mysich nokaut genu sirtuiny 7 prowadzi do zwiększonego poziomu acetylowanych histonów H3K18, co obniża zdolność komórki do naprawy pęknięć dwuniciowych na drodze NHEJ [49].

\section{PARP A SIRTUINY}

Polimerazy poli(ADP-rybozy) - PARPs katalizują konserwatywną ewolucyjnie modyfikację potranslacyjną, $\mathrm{w}$ której reszty APD-rybozy z NAD ${ }^{+}$zostają przeniesione na reszty aminokwasowe wielu białek, tworząc struktury polimerowe. Rodzina PARP składa się z 17 białek, z czego PARP1 odpowiedzialne jest za większość reakcji rybozylacji w komórce. Pierwszymi zidentyfikowanymi czynnikami prowadzącymi do aktywacji PARP były pęknięcia dwuniciowe, do których białka wiążą się poprzez motyw palca cynkowego. Delecja genów kodujących PARP1 oraz PARP2 lub zastosowanie inhibitorów PARP zwiększa wrażliwość komórek na czynniki uszkadzające DNA. Ogony PAR (polimery ADP-rybozy) funkcjonują bowiem jako rusztowanie dla białek naprawczych, umożliwiając wydajną naprawę jedno- oraz dwuniciowych pęknięć DNA oraz wspomagają prawidłowe działanie systemu BER. Można przypuszczać, że PARP konkuruje z sirtuinami o dostępność $\mathrm{NAD}^{+}$, który jest głównym źródłem monomerów ADP-rybozy. Istnienie takiej zależności jest jednak mało prawdopodobne np. dla SIRT1, gdzie zmniejszenie aktywności PARP1 może być wynikiem wyczerpania wewnątrzkomórkowych zasobów $\mathrm{NAD}^{+}$. Ograniczenie takie może być natomiast efektem bezpośredniej interakcji między białkami lub wynikiem deacetylacji PARP1 [50].

Kolejne badania sugerują odwrotną zależność, gdzie PARP1, w sposób pośredni, poprzez zużycie zasobów $\mathrm{NAD}^{+}$(spadek do $20-30 \%$ poziomu podstawowego) ogranicza aktywność białka SIRT1. Zależności takiej nie obserwuje się dla sirtuin, których lokalizacja jest inna niż jądrowa. PARP2 jest natomiast represorem tranksrypcyjnym genu SIRT1 [50]. Warto podkreślić, że aktywność sirtuin jest ściśle regulowana przez NAM - produkt reakcji katalitycznej PARP oraz sirtuin, co $\mathrm{w}$ połączeniu $\mathrm{z}$ kompartmentacją $\mathrm{NAD}^{+}$nadaje regulacji wysoki stopień złożoności $[51,52]$. 


\section{PODSUMOWANIE}

Sirtuiny stanowią interesującą rodzinę wyspecjalizowanych enzymów o aktywności deacetylazy oraz mono-ADP-rybozylotransferazy. Występują we wszystkich domenach życia, gdzie pełnią istotną rolę w regulacji szerokiego zakresu procesów biologicznych, w tym wyciszania ekspresji genów, apoptozy oraz metabolizmu. Szczególną rolę pełnią situiny w procesie naprawy DNA. Kluczowe dla zrozumienia działania sirtuin w tym procesie są ich powiązania ze stanem metabolicznym komórki (stężenie NAD ${ }^{+}$) w przestrzeniach komórkowych. Będący kofaktorem oraz produktem wielu reakcji $\mathrm{NAD}^{+}$stanowi element zespalający wiele procesów zachodzących w komórce. Deacetylacja przeprowadzana przez sirtuiny należy do podstawowych mechanizmów epigenetycznych regulujących stopień upakowania chromatyny. Największy udział w procesach naprawy DNA mają bez wątpienia sirtuina 1 i 6 . Deacetylacja przez SIRT1 endonukleazy AP zwiększa jej aktywność, a tym samym wydajność systemu BER. Z kolei, deacetylacja białek XPA i XPC przez sirtuinę $1 \mathrm{w}$ systemie NER zwiększa jego efektywność poprzez stabilizację kompleksu enzymów uczestniczących w naprawie DNA. Sirtuiny odgrywają również kluczową rolę w naprawie pęknięć dwuniciowych wchodząc w interakcje z białkami systemu niehomologicznego łączenia końców DNA (NHEJ) oraz składnikami systemu naprawy wykorzystującego homologie (HR). Sirtuina 6 jest wymagana do prawidłowej naprawy pęknięć dwuniciowych w DNA, a zwiększenie jej aktywności poprzez ADP-rybozylację PARP1 wpływa na wzrost wydajności systemów naprawczych w komórce. Zrozumienie skomplikowanych połączeń krzyżowych pomiędzy sirtuinami, białkami naprawy DNA oraz stanem chromatyny, pozwoli na skuteczniejsze leczenie wielu chorób, w tym nowotworowych.

\section{PIŚMIENNICTWO}

1. Hagis MC, Sinclair DA (2010) Mammalian sirtuins: biological insights and disease relevance. Annu Rec Pathol 5: 253-295

2. Frydzińska Z, Owczarek A, Winiarska K (2019) Sirtuiny i ich rola w regulacji metabolizmu. Postępy Biochemii 65: 31-40

3. Haigis MC, Guarente LP (2006) Mammalian sirtuins - emerging roles in physiology, aging, and calorie restriction. Genes Dev 20: 2913-2921

4. Chatterjee N, Walker GC (2017) Mechanisms of DNA damage, repair, and mutagenesis. Environmental and molecular mutagenesis 58: 235263

5. Jackson SP, Bartek J (2009) The DNA-damage response in human biology and disease. Nature 461: 1071-1078

6. Poulose N, Raju R (2015) Sirtuin regulation in aging and injury. Biochim Biophys Acta 1852: 2442- 2455

7. Lim CS (2006) SIRT1: Tumor promoter or tumor suppressor? Med Hypotheses. 67: 341-344

8. Wang RH, Sengupta K, Li C, Kim HS, Cao L, Xiao C, Kim S, Xu X, Zheng Y, Chilton B, Jia R, Zheng ZM, Appella E, Wang XW, Ried T, Deng CX (2008) Impaired DNA damage response, genome instability, and tumorigenesis in SIRT1 mutant mice. Cancer Cell 14: 312-323

9. Luo J, Nikolaev AY, Imai S, Chen D, Su F, Shiloh A, Guarente L, Gu W (2001) Negative control of p53 by Sir2a promotes cell survival under stress. Cell 107: 137-148

10. Cheng HL, Mostoslavsky R, Saito S, Manis JP, Gu Y, Patel P, Bronson R, Appella E, Alt FW, Chua KF (2003) Developmental defects and p53 hyperacetylation in Sir2 homolog (SIRT1)-deficient mice. Proc Natl Acad Sci USA 100: 10794-10799
11. Chen WY, Wang DH, Yen RC, Luo J, Gu W, Baylin SB (2005) Tumor suppressor HIC1 directly regulates SIRT1 to modulate p53-dependent DNA-damage responses. Cell 123: 437-448

12. Wang C, Chen L, Hou X, Li Z, Kabra N, Ma Y, Nemoto S, Finkel T, Gu W, Cress WD, Chen J (2006) Interactions between E2F1 and SirT1 regulate apoptotic response to DNA damage. Nat Cell Biol 8: 1025-1031

13. Nakae J, Cao Y, Daitoku H, Fukamizu A, Ogawa W, Yano Y, Hayashi Y (2006) The LXXLL motif of murine forkhead transcription factor FoxO1 mediates Sirt1-dependent transcriptional activity. J Clin Invest 116: $2473-2483$

14. Li J, Wang E, Rinaldo F, Datta K (2005) Upregulation of VEGF-C by androgen depletion: the involvement of IGF-IR - FOXO pathway. Oncogene 24: 5510-5520

15. Motta MC, Divecha N, Lemieux M, Kamel C, Chen D, Gu W, Bultsma Y, McBurney M, Guarente L (2004) Mammalian SIRT1 represses forkhead transcription factors. Cell 116: 551-563

16. Brunet A, Sweeney LB, Sturgill JF, Chua KF, Greer PL, Lin Y, Tran H, Ross SE, Mostoslavsky R, Cohen HY, Hu LS, Cheng HL, Jedrychowski MP, Gygi SP, Sinclair DA, Alt FW, Greenberg ME (2004) Stress-dependent regulation of FOXO transcription factors by the SIRT1 deacetylase. Science 303: 2011-2015

17. van der Horst A, Tertoolen LG, de Vries-Smits LM, Frye RA, Medema $\mathrm{RH}$, Burgering BM (2004) FOXO4 is acetylated upon peroxide stress and deacetylated by the longevity protein hSir2 (SIRT1). J Biol Chem 279: 28873-28879

18. Kobayashi Y, Furukawa-Hibi Y, Chen C, Horio Y, Isobe K, Ikeda K, Motoyama N. (2005) SIRT1 is critical regulator of FOXO-mediated transcription in response to oxidative stress. Int J Mol Med 16: 237-243

19. Tamura RE, de Vasconcellos JF, Sarkar D, Libermann TA, Fisher PB, Zerbini LF (2012) GADD45 proteins: central players in tumorigenesis. Curr Mol Med 12: 634-51

20. Firestein R, Blander G, Michan S, Oberdoerffer P, Ogino S, Campbell J, Bhimavarapu A, Luikenhuis S, de Cabo R, Fuchs C, Hahn WC, Guarente LP, Sinclair DA (2008) The SIRT1 deacetylase suppresses intestinal tumorigenesis and colon cancer growth. PLoS ONE 3: e2020

21. Wang RH, Zheng Y, Kim HS, Xu X, Cao L, Luhasen T, Lee MH, Xiao C, Vassilopoulos A, Chen W, Gardner K, Man YG, Hung MC, Finkel T, Deng CX. (2008) Interplay among BRCA1, SIRT1, and Survivin during BRCA1-associated tumorigenesis. Mol Cell 32: 11-20

22. Cohen HY, Lavu S, Bitterman KJ, Hekking B, Imahiyerobo TA, Miller C, Frye R, Ploegh H, Kessler BM, Sinclair DA (2004) Acetylation of the $\mathrm{C}$ terminus of Ku70 by CBP and PCAF controls Bax-mediated apoptosis. Mol Cell 13: 627-638

23. Yuan Z, Zhang X, Sengupta N, Lane WS, Seto E (2007) SIRT1 regulates the function of the Nijmegen breakage syndrome protein. Mol Cell 27: 149-162

24. Li K, Casta A, Wang R, Lozada E, Fan W, Kane S, Ge Q, Gu W, Orren D, Luo J (2008) Regulation of WRN protein cellular localization and enzymatic activities by SIRT1-mediated deacetylation. J Biol Chem 283: 7590-7598

25. Oberdoerffer P, Michan S, McVay M, Mostoslavsky R, Vann J, Park SK, Hartlerode A, Stegmuller J, Hafner A, Loerch P, Wright SM, Mills KD, Bonni A, Yankner BA, Scully R, Prolla TA, Alt FW, Sinclair DA (2008) SIRT1 redistribution on chromatin promotes genomic stability but alters gene expression during aging. Cell 135: 907-918

26. Sasaki T, Maier B, Koclega KD, Chruszcz M, Gluba W, Stukenberg PT, Minor W, Scrable H (2008) Phosphorylation regulates SIRT1 function. PLoS One 3: e4020

27. Yamamori T, DeRicco J, Naqvi A, Hoffman TA, Mattagajasingh I, Kasuno K, Jung S-B, Kim C-S, Irani K (2010) SIRT1 deacetylates APE1 and regulates cellular base excision repair. Nucl Acids Res 38: 832-845

28. Madabushi A, Hwang BJ, Jin J, Lu AL (2013) Histone deacetylase SIRT1 modulates and deacetylates DNA base excision repair enzyme thymine DNA glycosylase. Biochem J 456: 89-98

29. Fan W, Luo J. SIRT1 Regulates UV-Induced DNA Repair through Deacetylating XPA (2010) Mol Cell 39: 247-258 
30. Ming M, Shea CR, Guo X, Li X, Soltani K, Han W, He YY (2010) Regulation of global genome nucleotide excision repair by SIRT1 through xeroderma pigmentosum C. Proc Natl Acad Sci U S A 107: 22623 22628

31. Jang J, Huh YJ, Cho HJ, Lee B, Park J, Hwang DY, Kim DW (2007) SIRT1 Enhances the survival of human embryonic stem cells by promoting DNA repair. Stem Cell Rep9(2): 629-641

32. Vaquero A, Scher M, Erdjument-Bromage H, Tempst P, Serrano L, Reinberg D (2007) SIRT1 regulates the histone methyl-transferase SUV39H1 during heterochromatin formation. Nature 450: 440-444

33. Wang J, Chen J (2010) SIRT1 regulates autoacetylation and histone acetyltransferase activity of TIP60. J Biol Chem 285: 11458-11464

34. Zhang H, Park SH, Pantazides BG, Karpiuk O, Warren MD, Hardy CW, Duong DM, Park SJ, Kim HS, Vassilopoulos A, Seyfried NT, Johnsen SA, Gius D, Yu DS (2013) SIRT2 directs the replication stress response through CDK9 deacetylation. Proc Nat Acad Sci 110: 1354613551

35. Serrano L, Martínez-Redondo P, Marazuela-Duque A, Vazquez BN, Dooley SJ, Voigt P, Beck DB, Kane-Goldsmith N, Tong Q, Rabanal RM, Fondevila D, Muñoz P, Krüger M, Tischfield JA, Vaquero A (2013) The tumor suppressor SirT2 regulates cell cycle progression and genome stability by modulating the mitotic deposition of H4K20 methylation. Genes Dev 27: 639-653

36. Das C, Lucia MS, Hansen KC, Tyler JK (2009) CBP/p300-mediated acetylation of histone $\mathrm{H} 3$ on lysine 56 . Nature 459: 113-117

37. Fang EF, Scheibye-Knudsen M, Chua KF, Mattson MP, Croteau DL, Bohr VA (2016) Nuclear DNA damage signalling to mitochondria in ageing. Nat Rev Mol Cell Biol 17: 308-321

38. Scher MB, Vaquero A, Reinberg D (2007) SirT3 is a nuclear NAD+-dependent histone deacetylase that translocates to the mitochondria upon cellular stress. Genes Dev 21: 920-928

39. Tennen RI, Chua KF (2011) Chromatin regulation and genome maintenance by mammalian SIRT6. Trends Biochem Sci 36: 39-46.

40. Mostoslavsky R, Chua KF, Lombard DB, Pang WW, Fischer MR, Gellon L, Liu P, Mostoslavsky G, Franco S, Murphy MM, Mills KD, Patel P, Hsu JT, Hong AL, Ford E, Cheng HL, Kennedy C, Nunez N, Bronson R, Frendewey D, Auerbach W, Valenzuela D, Karow M, Hottiger MO, Hursting S, Barrett JC, Guarente L, Mulligan R, Demple B, Yancopoulos GD, Alt FW (2006) Genomic instability and aging-like phenotype in the absence of mammalian SIRT6. Cell 124: 315-329

41. McCord RA, Michishita E, Hong T, Berber E, Boxer LD, Kusumoto R, Guan S, Shi X, Gozani O, Burlingame AL, Bohr VA, Chua KF (2009)
SIRT6 stabilizes DNA-dependent protein kinase at chromatin for DNA double-strand break repair. Aging (Albany NY) 1: 109-121

42. Mao Z, Hine C, Tian X, Van Meter M, Au M, Vaidya A, Seluanov A, Gorbunova V (2011) SIRT6 promotes DNA repair under stress by activating PARP1. Science 332: 1443-1446

43. Schreiber V, Ame JC, Dolle P, Schultz I, Rinaldi B, Fraulob V, Menissier-de Murcia J, de Murcia G (2002) Poly(ADP-ribose) polymerase-2 (PARP-2) is required for efficient base excision DNA repair in association with PARP-1 and XRCC1. J Biol Chem 277: 23028-23036

44. Hwang BJ, Jin J, Gao Y, Shi G, Madabushi A, Yan A, Guan X, Zalzman M, Nakajima S, Lan L, Lu AL (2015) SIRT6 protein deacetylase interacts with MYH DNA glycosylase, APE1 endonuclease, and Rad9-Rad1-Hus1 checkpoint clamp. BMC Mol Biol 16: 12

45. Toiber D, Erdel F, Bouazoune K, Silberman DM, Zhong L, Mulligan P, Sebastian C, Cosentino C, Martinez-Pastor B, Giacosa S, D'Urso A, Näär AM, Kingston R, Rippe K, Mostoslavsky R (2013) SIRT6 recruits $\mathrm{SNF} 2 \mathrm{H}$ to DNA break sites, preventing genomic instability through chromatin remodeling. Mol Cell 51: 454-468

46. Ford E, Voit R, Liszt G, Magin C, Grummt I, Guarente L (2006) Mammalian Sir2 homolog SIRT7 is an activator of RNA polymerase I transcription. Genes Dev 20: 1075-1080

47. Vakhrusheva O, Smolka C, Gajawada P, Kostin S, Boettger T, Kubin T, Braun T, Bober E (2008) Sirt7 increases stress resistance of cardiomyocytes and prevents apoptosis and inflammatory cardiomyopathy in mice. Circ Res 102: 703-710

48. Barber MF, Michishita-Kioi E, Xi Y, Tasselli L, Kioi M, Moqtaderi Z, Tennen RI, Paredes S, Young NL, Chen K, Struhl K, Garcia BA, Gozani O, Li W, Chua KF (2012) SIRT7 links H3K18 deacetylation to maintenance of oncogenic transformation. Nature 487: 114-118

49. Vazquez B.N., Thackray J.K., Simonet N.G., Kane-Goldsmith N., Martinez-Redondo P., Nguyen T., Bunting S., Vaquero A., Tischfield J.A., Serrano L (2016) SIRT7 promotes genome integrity and modulates non-homologous end joining DNA repair. EMBO J 35: 1488-1503

50. Cantó C, Sauve AA, Bai P (2013) Crosstalk between poly(ADP-ribose) polymerase and sirtuin enzymes. Mol Aspects Med 34: 1168-201

51. Houtkooper RH, Canto C, Wanders RJ, Auwerx J (2010) The secret life of NAD+: an old metabolite controlling new metabolic signaling pathways. Endocr Rev 31: 194-223

52. Revollo JR, Grimm AA, Imai S (2004) The NAD biosynthesis pathway mediated by nicotinamide phosphoribosyltransferase regulates Sir2 activity in mammalian cells. J Biol Chem 279: 50754-50763

\section{Sirtuins in DNA repair}

\section{mgr Mateusz Kciuk ${ }^{1,2 \square}$, dr hab. Renata Kontek ${ }^{1}$}

${ }^{1}$ Department of Molecular Biotechnology and Genetics, Faculty of Biology and Environmental Protection, University of Lodz ${ }^{2}$ University of Lodz, Doctoral School of Exact and Natural Sciences, Lodz

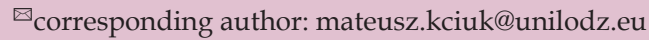

Keywords: DNA repair, sirtuins

\section{SUMMARY}

DNA repair involves number of processes required for detection and repair of DNA damage. The ability to repair existing damage is crucial for preservation of both physical integrity of the genome and fidelity of genetic information. Genetic insults may derive from either metabolic reactions inside the cell or come from exogenous environment. Sirtuins belong to the class of histone deacetylases that catalyze the removal of acetyl moieties from the lysine residues of both histone and nonhistone proteins. Furthermore, some sirtuins exhibit mono-ADP-ribosyltransferase activity that regulates activity of various proteins. The first sirtuin was identified in yeast (Saccharomyces cerevisiae), however both prokaryotic and eukaryotic homologs of sirtuins were later discovered. Seven mammalian homologs (SIRT1-SIRT7) exist. Sirtuins represent an emerging group of enzymes that coordinate DNA repair in respect of cellular metabolic status and may have a prominent role in neoplastic transformation, diabetes, ageing and age-related diseases such as neurodegeneration. The aim of this paper is to review recent research on the role of sirtuins in DNA repair processes. 